\title{
Topoisomerase II-Drug Interaction Domains: Identification of Substituents on Etoposide that Interact with the Enzyme ${ }^{\dagger}$
}

\author{
Amy M. Wilstermann $\ddagger$,@, Ryan P. Bender ${ }^{\ddagger}$, Murrell Godfrey $\rrbracket$, Sungjo Choi $^{\perp}$, Clemens \\ Anklin $\mid$, David B. Berkowitz ${ }^{\perp}$, Neil Osheroff $¥, \#,{ }^{*}$, and David E. Graves $\S,{ }^{*}$ \\ ‡Department of Biochemistry, Vanderbilt University School of Medicine, Nashville, TN 37232-0146 \\ \#Department of Medicine (Hematology/Oncology), Vanderbilt University School of Medicine, \\ Nashville, TN 37232-0146 \\ @Department of Science and Mathematics, Trevecca Nazarene University, Nashville, TN 37210 \\ IDepartment of Chemistry, University of Mississippi, University, MS 38677 \\ $\S$ Department of Chemistry, University of Alabama at Birmingham, Birmingham, AL 35294 \\ ${ }^{\perp}$ Department of Chemistry, University of Nebraska-Lincoln, Lincoln, NE 68588-0304 \\ IBruker BioSpin Corporation, Billerica, MA 01821
}

\begin{abstract}
Etoposide is one of the most successful chemotherapeutic agents used for the treatment of human cancers. The drug kills cells by inhibiting the ability of topoisomerase II to ligate nucleic acids that it cleaves during the double-stranded DNA passage reaction. Etoposide is composed of a polycyclic ring system (rings $\mathrm{A}-\mathrm{D}$ ), a glycosidic moiety at the $\mathrm{C} 4$ position, and a pendant ring (E-ring) at the $\mathrm{C} 1$ position. Although drug-enzyme contacts, as opposed to drug-DNA interactions, mediate the entry of etoposide into the topoisomerase II-drug-DNA complex, the substituents on etoposide that interact with the enzyme have not been identified. Therefore, saturation transfer difference $\left[{ }^{1} \mathrm{H}\right]$ nuclear magnetic resonance spectroscopy and protein-drug competition binding assays were employed to define the groups on etoposide that associate with yeast topoisomerase II and human topoisomerase II $\alpha$. Results indicate that the geminal protons of the A-ring, the $\mathrm{H} 5$ and $\mathrm{H} 8$ protons of the B-ring, as well as the $\mathrm{H} 2$ ' and $\mathrm{H} 6$ ' protons and the 3'- and 5'-methoxyl protons of the pendent E-ring interact with both enzymes in the binary protein-ligand complexes. In contrast, no significant nuclear Overhauser enhancement signals arising from the $\mathrm{C}$-ring, the $\mathrm{D}$-ring, or the $\mathrm{C} 4$ glycosidic moiety were observed with either enzyme, suggesting that there is limited or no contact between these portions of etoposide and topoisomerase II in the binary complex. The functional importance of E-ring substituents was confirmed by topoisomerase II-mediated DNA cleavage assays.
\end{abstract}

Etoposide is one of the most successful chemotherapeutic agents used for the treatment of human cancers (1-4). The drug currently is in its third decade of clinical use and is front line

\footnotetext{
$\dagger$ This work was supported by National Institutes of Health grant GM33944 (NO), National Science Foundation grant MCB-0334785 (DEG), and American Cancer Society grant RPG-96-001-05-CDD (DBB). DBB was an Alfred P. Sloan Research Fellow, and AMW and RPB were trainees under National Institutes of Health grant T32 CA09582.

"Correspondence regarding DNA topoisomerase II should be addressed to Neil Osheroff: Tel: 615-322-4338. Fax: 615-343-1166. neil.osheroff@ vanderbilt.edu. 'Correspondence regarding NMR should be addressed to David E. Graves: Tel: 205-975-5381. FAX: 205-975-2543.dgraves@uab.edu.

SUPPORTING INFORMATION AVAILABLE

A representative $\left[{ }^{1} \mathrm{H}\right]-\mathrm{NMR}$ spectrum of etoposide with complete assignments for all of the visible protons is available free of charge via the Internet at http://pubs.acs.org.
} 
therapy for a variety of malignancies, including leukemias, lymphomas, and several solid tumors (1-4). Until the development of paclitaxel and related compounds, etoposide was the most widely prescribed anticancer drug in the world.

The cellular target for etoposide is topoisomerase II (1-5). This essential enzyme relaxes, unknots, and untangles DNA by passing a double helix through a transient double-stranded break that it generates in a separate segment of DNA (6-12). Etoposide acts specifically by inhibiting the ability of topoisomerase II to ligate DNA molecules that it has cleaved $(13,14)$. This drug-induced inhibition leads to the accumulation of covalent, topoisomerase II-cleaved DNA complexes (i.e., cleavage complexes) (5). When DNA tracking enzymes such as polymerases or helicases collide with these complexes, they convert them to permanent enzyme-linked double-stranded breaks in the genetic material (6-12). These breaks destabilize the genome and when present in sufficient concentrations, trigger programmed cell death pathways $(9,15-21)$.

Several lines of evidence indicate that interactions between topoisomerase II and etoposide, as opposed to drug-DNA interactions, are critical for drug activity and mediate the entry of etoposide into the ternary enzyme-drug-DNA complex. First, mutation of specific residues in topoisomerase II dramatically affects the ability of etoposide to increase levels of enzymeDNA cleavage complexes $(4,9,22-28)$. Second, etoposide binds weakly (if at all) to DNA in the absence of topoisomerase II (29). Third, the drug binds to yeast topoisomerase II and human topoisomerase II $\alpha$ in the absence of nucleic acids and a mutant yeast enzyme (yTop2H1011Y) that is resistant to etoposide displays a reduced binding affinity for the agent $(30,31)$. Fourth, etoposide displays a similar kinetic affinity for topoisomerase II-DNA cleavage complexes formed at sites with markedly different levels of scission enhancement (32). Finally, DNA breaks accumulate more rapidly when etoposide is incubated with topoisomerase II prior to the addition of DNA (as compared to the opposite order of addition) (32).

Hundreds of etoposide derivatives have been analyzed in an effort to establish structure-activity relationships within this drug class (33-42). Despite the importance of protein-drug interactions, none of these studies have identified any of the substituents on etoposide that interact with topoisomerase II. Therefore, the present study utilized saturation transfer difference $\left[{ }^{1} \mathrm{H}\right]$-nuclear magnetic resonance (STD $\left[{ }^{1} \mathrm{H}\right]-\mathrm{NMR}$ ) spectroscopy (43-47) and protein-drug competition binding assays to define the groups on the drug that associate with the type II enzyme. Results indicate that substituents on the A-, B-, and E-rings of etoposide interact with yeast topoisomerase II and human topoisomerase II $\alpha$. The functional importance of E-ring substituents was confirmed by topoisomerase II-mediated DNA cleavage assays.

\section{EXPERIMENTAL PROCEDURES}

\section{Materials}

Negatively supercoiled pBR322 plasmid DNA was prepared using a Plasmid Mega Kit (Qiagen) as described by the manufacturer. Etoposide was purchased from Sigma. Teniposide was provided by Bristol-Meyers Squibb. The synthesis of etoposide derivatives with modified E-ring substituents will be described elsewhere. TOP-53 was provided as a dichloride salt by Taiho Pharmaceuticals. All drugs were stored at $4{ }^{\circ} \mathrm{C}$ as $20 \mathrm{mM}$ stock solutions in $100 \%$ DMSO. Drugs used for NMR experiments were stored in $100 \%$ d-DMSO. $\left[{ }^{3} \mathrm{H}\right]$ etoposide was obtained from Moravek Biochemicals as a $1.5 \mathrm{mM}$ stock in $100 \%$ ethanol. $\mathrm{D}_{2} \mathrm{O}(99.9 \%)$ was purchased from Aldrich. All other chemicals were analytical reagent grade. 


\section{Purification of Type II Topoisomerases}

Highly concentrated yeast topoisomerase II and human topoisomerase II $\alpha$ were expressed in Saccharomyces cerevisiae and purified as described $(26,48,49)$. The yeast and human enzymes were purified from 50-60 g of frozen wet-packed yeast JEL 1 cells transformed with YEpGAL1TOP or YEpWOB6, respectively. In the final step of the purification, the type II topoisomerases were eluted from phosphocellulose columns (P81, Whatman) with buffer containing $10 \mathrm{mM}$ sodium phosphate, $\mathrm{pH}$ 7.7, $750 \mathrm{mM} \mathrm{KCl}, 1 \mathrm{mM}$ EDTA, 1 mM EGTA, 0.5 $\mathrm{mM}$ dithiothreitol, and 5\% d-glycerol in $\mathrm{D}_{2} \mathrm{O}$. Typical yields exceeded $1 \mathrm{mg}$ of yeast topoisomerase II or $0.2 \mathrm{mg}$ of human topoisomerase II $\alpha$ per $\mathrm{g}$ of wet-packed yeast cells.

\section{Cleavage of Plasmid DNA by Yeast Topoisomerase II}

DNA cleavage reactions were carried out as described (26). Reaction mixtures contained 150 $\mathrm{nM}$ yeast topoisomerase II and $5 \mu \mathrm{M}$ negatively supercoiled pBR322 in a total of $20 \mu \mathrm{L}$ of 10 $\mathrm{mM}$ sodium phosphate, $\mathrm{pH} 7.7,100 \mathrm{mM} \mathrm{KCl}, 0.1 \mathrm{mM} \mathrm{NaEDTA}, 5 \mathrm{mM} \mathrm{MgCl}{ }_{2}$ containing etoposide, teniposide, TOP-53, hydroxyphenyl-etoposide, or phenyl-etoposide (up to $300 \mu \mathrm{M}$ ) solubilized in 100\% DMSO (all reactions contained 10\% DMSO final concentration). DNA cleavage was initiated by the addition of enzyme and reaction mixtures were incubated for 6 min at $28{ }^{\circ} \mathrm{C}$ to establish DNA cleavage/religation equilibria. Cleavage complexes were trapped by the addition of $2 \mu \mathrm{L}$ of $5 \%$ SDS and $1.5 \mu \mathrm{L}$ of $250 \mathrm{mM}$ NaEDTA, pH 8.0. Proteinase $\mathrm{K}$ was added $(2 \mu \mathrm{L}$ of $0.8 \mathrm{mg} / \mathrm{mL})$ and reaction mixtures were incubated for $30 \mathrm{~min}$ at $45^{\circ} \mathrm{C}$ to digest the topoisomerase II. Samples were mixed with $2 \mu \mathrm{L}$ of $30 \%$ sucrose, $0.5 \%$ bromophebol blue, and $0.5 \%$ xylene cyanol FF in $10 \mathrm{mM}$ Tris-HCl, $\mathrm{pH} 7.9$, heated for $2 \mathrm{~min}$ at $45^{\circ} \mathrm{C}$, and subjected to electrophoresis in a $1 \%$ agarose gel in $40 \mathrm{mM}$ Tris-acetate, $2 \mathrm{mM}$ NaEDTA containing $0.5 \mu \mathrm{g} / \mathrm{mL}$ ethidium bromide. Cleavage was monitored by the conversion of negatively supercoiled DNA to linear molecules. DNA was visualized by medium wavelength UV light and quantified using an Alpha Innotech digital imaging system.

\section{STD [ $\left.{ }^{1} \mathrm{H}\right]$-NMR Spectroscopy}

All NMR experiments are performed at $283 \mathrm{~K}$ using a Bruker Avance DRX 500-MHz spectrometer equipped with a 5-mm BBI probe. NMR buffers were prepared in $99.9 \% \mathrm{D}_{2} \mathrm{O}$ and contained $10 \mathrm{mM}$ sodium phosphate, $\mathrm{pH} 7.7,250 \mathrm{mM} \mathrm{KCl}, 0.1 \mathrm{mM} \mathrm{Na} 2 \mathrm{EDTA}$, and $5 \mathrm{mM}$ $\mathrm{MgCl}_{2}$. NMR samples $(500 \mu \mathrm{L})$ contained $5 \mu \mathrm{M}$ yeast topoisomerase II or human topoisomerase II $\alpha$ and $100-400 \mu \mathrm{M}$ etoposide or selected analogs, and were maintained at $5^{\circ}$ $\mathrm{C}$ until data were obtained. STD-NMR experiments employed a pulse scheme similar to that reported by Mayer and Meyer (46). The gradient pulse that was applied was $1 \mathrm{~ms}$ at $30 \%$ with a $500 \mu$ s recovery delay. The water signal was suppressed by tailoring a watergate pulse sequence to the beginning of the 2 presaturation STD-pulse program. For each experiment (on and off resonance irradiation), a total of 2000 scans were collected with a 3 s relaxation delay between each scan. On and off-resonance irradiations were performed at 0.5 and $17 \mathrm{ppm}$, respectively. Difference spectra were prepared by subtracting the on-resonance spectrum from the off-resonance spectrum. Signals resulting in the difference spectrum represent the NOE difference signals generated by the transfer of irradiation energy from the enzyme to the bound ligand. Ligand protons in close spatial proximity with the enzyme displayed larger NOE signals. Mapping of the NOE signals with their proton assignments on the ligand revealed the ligand binding epitope to the target topoisomerase II. Spectra were processed using Bruker XWINNMR (v3.2) software.

\section{Topoisomerase II-Drug Binding}

Competition binding studies were performed using a nitrocellulose filter binding technique. Nitrocellulose membranes ( $0.45 \mu \mathrm{m}$ HA; Millipore) were soaked in binding buffer $(10 \mathrm{mM}$ sodium phosphate, $\mathrm{pH} 7.7,250 \mathrm{mM} \mathrm{KCl}, 0.1 \mathrm{mM} \mathrm{NaEDTA}$, and $5 \mathrm{mM} \mathrm{MgCl}_{2}$ ) for $10 \mathrm{~min}$. 
Reaction mixtures contained $1.6 \mu \mathrm{M}$ yeast topoisomerase II and $20 \mu \mathrm{M}\left[{ }^{3} \mathrm{H}\right]$ etoposide, as well as 0-100 $\mu \mathrm{M}$ etoposide, TOP-53, hydroxyphenyl-etoposide or phenyl-etoposide in a total of $60 \mu \mathrm{L}$ of binding buffer. Samples were incubated for $6 \mathrm{~min}$ at $30^{\circ} \mathrm{C}$ and applied to the nitrocellulose membranes in vacuo. Filters were immediately washed three times with $1 \mathrm{~mL}$ of ice-cold binding buffer, dried, and submerged in $8 \mathrm{~mL}$ of scintillation fluid (Econo-Safe; Research Products International). Radioactivity remaining on membranes was quantified using a Beckman LS 5000 TD scintillation counter. The amount of radioactive etoposide remaining on the filter in the absence of enzyme was subtracted prior to binding calculations.

\section{RESULTS}

\section{Interaction of Etoposide with Topoisomerase II}

Etoposide, a semisynthetic derivative of podophyllotoxin, is an important anticancer agent (1-4). It is composed of a polycyclic ring system (rings A-D), a glycosidic moiety at the C4 position, and a pendant ring (E-ring) at the $\mathrm{C} 1$ position (Figure 1) (1-4). The drug kills cells by inhibiting the ability of topoisomerase II to ligate nucleic acids that it cleaves during the double-stranded DNA passage reaction $(13,14)$. As a result of etoposide action, high levels of topoisomerase II-associated DNA breaks accumulate in treated cells (1-5). The effects of etoposide on DNA cleavage mediated by yeast topoisomerase II are shown in Figure 2.

In an effort to identify the substituents that influence drug activity, numerous derivatives of etoposide have been synthesized (33-42). Most of the modifications have focused on the glycosidic moiety and the E-ring (35,37-40). Many of these changes have profound effects on the cellular activity of etoposide. However, for most substitutions, it is not known whether alterations in drug potency or efficacy are caused by changes in drug uptake/efflux or metabolism, as opposed to a direct effect on topoisomerase II-mediated DNA ligation. Even in the small number of cases in which the effects of drug derivatives on the purified enzyme have been assessed, it has not been possible to ascribe a specific function to any given substitutent on etoposide $(35,39,40)$.

Given the wide clinical use of etoposide, it is important to understand how the drug interacts with its protein target. Therefore, STD $\left[{ }^{1} \mathrm{H}\right]$-NMR spectroscopy (43-47) was employed to identify the substituents on etoposide that interact with topoisomerase II. Since drug-enzyme contacts, as opposed to drug-DNA interactions, mediate the entry of etoposide into the topoisomerase II-drug-DNA complex $(4,9,22-32)$, the present study focused on interactions between etoposide and topoisomerase II in the binary protein-ligand complex.

In the STD $\left[{ }^{1} \mathrm{H}\right]-N M R$ technique (43-47), topoisomerase II is selectively saturated with magnetization by irradiating the sample at a frequency at which no drug protons resonate (onresonance frequency). Magnetization is spread very rapidly throughout the protein by intramolecular spin diffusion. Substituents on the drug (i.e., ligand) that interact with topoisomerase II are progressively saturated with magnetization via intermolecular, throughspace, dipole-dipole interactions. The NMR spectrum generated following on-resonance irradiation is subtracted from an off-resonance (or reference) spectrum. This off-resonance spectrum is taken following saturation of the sample with a magnetization frequency that is different from the resonance frequencies of either topoisomerase II or the drug. The resulting difference spectrum contains only the signals of the drug substituents that interact with the enzyme and are saturated through the intermolecular transfer of magnetization from the protein (43-47).

NMR samples contained $5 \mu \mathrm{M}$ yeast topoisomerase II and $200 \mu \mathrm{M}$ drug, and spectra were recorded at $15{ }^{\circ} \mathrm{C}$. The buffer used for spectroscopy contained $10 \mathrm{mM}$ sodium phosphate and $250 \mathrm{mM} \mathrm{KCl}$, as opposed to $10 \mathrm{mM}$ Tris- $\mathrm{Cl}$ and $100 \mathrm{mM} \mathrm{KCl}$, which generally is used to assess 
topoisomerase II-mediated DNA cleavage (26). The use of phosphate eliminated the proton spectrum of the Tris buffer, which overwhelmed many of the drug peaks. In addition, the increased salt was required in order to maintain enzyme solubility at the high protein concentration and low temperature used for NMR. As seen in Figure 2, topoisomerase II maintained high DNA cleavage activity in the NMR buffer. Under the experimental conditions employed, enzyme-drug samples were stable for at least $24 \mathrm{~h}$ as assessed by NMR spectroscopy and DNA cleavage assays (data not shown).

As a prelude to STD $\left[{ }^{1} \mathrm{H}\right]-\mathrm{NMR}$ experiments, proton resonances of etoposide were assigned by 1-D NMR analysis (50) (a spectrum that includes these assignments is shown in supplemental Figure S1). A representative STD $\left[{ }^{1} \mathrm{H}\right]-\mathrm{NMR}$ experiment that analyzed the binding of etoposide to yeast topoisomerase II is shown in Figure 3. The difference spectrum, which reveals the nuclear Overhauser enhancment (NOE) signals from the bound drug, is seen at the top. Results indicate that substituents on the A-, B-, and E-rings interact with topoisomerase II in the binary protein-ligand complex. More specifically, NOE signals were observed for the geminal protons of the A-ring (6.0 ppm), the H5 and H8 protons of the Bring (7.0 and $6.6 \mathrm{ppm}$, respectively), as well as the H2' and H6' protons (6.4 ppm) and the 3'and 5'-methoxyl protons of the pendent E-ring (3.8 ppm). In contrast, no significant NOE signals arising from the C-ring, the D-ring, or the C4 glycosidic moiety were observed, suggesting that there is limited or no contact between these portions of etoposide and the enzyme in the binary complex.

One caveat should be noted, however. Resonances for the three hydroxyl groups present in etoposide, the 2"-OH and 3"-OH of the glycosidic moiety and the 4'-OH of the E-ring, were obscured by the water peak and could not be visualized in any of the NMR spectra.

To determine whether conclusions based on yeast topoisomerase II could be extended to mammalian systems, interactions between etoposide and human topoisomerase II $\alpha$ were analyzed by STD $\left[{ }^{1} \mathrm{H}\right]-\mathrm{NMR}$ spectroscopy. The NOE signals in the difference spectrum generated for the binary topoisomerase II $\alpha$-etoposide complex were similar to those described above for yeast topoisomerase II (Figure 3, third spectrum from top). Thus, it appears that the same etoposide substituents that interact with yeast topoisomerase II also interact with the human enzyme.

\section{C4 Substituents}

On the basis of the STD $\left[{ }^{1} \mathrm{H}\right]-\mathrm{NMR}$ data, it appears that the glycosidic moiety of etoposide, which is attached to the $\mathrm{C}$-ring at the $\mathrm{C} 4$ position, does not interact with yeast topoisomerase II or human topoisomerase II $\alpha$ in the binary enzyme-drug complex. To characterize the effects of alternative substituents at the $\mathrm{C} 4$ position, interactions between the yeast enzyme and two etoposide derivatives were characterized by STD $\left[{ }^{1} \mathrm{H}\right]-\mathrm{NMR}$. The first was teniposide, which, like etoposide, also is in clinical use $(1,2)$. Teniposide contains the $\mathrm{C} 4$ substituent of etoposide, except that the 8 "-methyl group is replaced by a thiophene moiety (see Figure 1). In all other respects, the two compounds are identical. NMR signals derived from the 8"-thiophene protons are shifted well downfield to a region of the spectrum that is devoid of protein peaks (6.96$7.37 \mathrm{ppm}$ ). Although teniposide is $\sim 10$-fold more potent than etoposide in human cells, the two drugs are equipotent in purified systems (see Figure 2). Thus, it is believed that the effects of the thiophene moiety are primarily physiological (uptake, metabolism, etc.) in nature $(1,2)$.

As seen in Figure 4 (top spectrum), difference spectrum NOE signals from the A-, B-, and Ering substituents of teniposide were similar to those of etoposide. In addition, no NOE signals from the glycosidic protons of the three thiophene protons were observed. These findings suggest that the $\mathrm{C} 4$ glycosidic moieties of etoposide and teniposide do not interact with topoisomerase II in the drug-enzyme complex. In support of this conclusion, the ability of 
etoposide and teniposide to enhance topoisomerase II-mediated DNA cleavage is identical (see Figure 2), despite the difference in the 8"-substituents of these two drugs.

The second derivative that was assessed was TOP-53. In contrast to etoposide and teniposide, TOP-53 contains a flexible dicationic amino-alkyl chain at the $\mathrm{C} 4$ position (see Figure 1) (51). Although TOP-53 is structurally identical to these compounds at all other positions, it exhibits a significantly greater ability ( $\sim$-fold higher potency) to stimulate DNA cleavage mediated by yeast (see Figure 2) or human type II topoisomerases (52). This finding implies that substituents at the $\mathrm{C} 4$ position have the capacity to alter drug actions in the ternary complex. Therefore, to determine whether the presence of the amino-alkyl chain of TOP-53 affects the interaction of the drug with the enzyme, drug-topoisomerase II interactions were assessed by STD $\left[{ }^{1} \mathrm{H}\right]-\mathrm{NMR}$.

As found for etoposide and teniposide, NOE signals were observed for the geminal protons of the A-ring, the $\mathrm{H} 5$ and $\mathrm{H} 8$ protons of the B-ring, as well as the H2' and H6' protons and the 3'- and 5'-methoxyl protons of the pendent E-ring (Figure 4, third spectrum from top).

However, the NOE signals for all of these positions on TOP-53 were $\sim 2$-fold stronger than those observed for the other podophyllotoxins. In addition, $\mathrm{NOE}$ signals for every $\mathrm{CH}_{2}$ group of the amino-alkyl side chain of TOP-53 (2.27-3.05 ppm) were observed (Figure 4).

These findings suggest that TOP-53 binds to yeast topoisomerase II more tightly or with a closer geometry than does etoposide. Unfortunately, the STD $\left[{ }^{1} \mathrm{H}\right]-\mathrm{NMR}$ technique employed cannot distinguish between these two possibilities. Therefore, nitrocellulose filter binding competition assays were utilized to address this issue. In these experiments, the ability of nonradioactive etoposide and TOP-53 to compete with $\left[{ }^{3} \mathrm{H}\right]$ etoposide for binding to yeast topoisomerase II was determined. As seen in Figure 5, the concentration of TOP-53 that was required to displace $\sim 50 \%$ of the bound $\left[{ }^{3} \mathrm{H}\right]$ etoposide was $\sim 4$-fold lower than needed by etoposide. These data demonstrate that the affinity of TOP- 53 for topoisomerase II is greater than that of etoposide, and likely accounts for the enhanced potency of the etoposide derivative. Furthermore, they imply that this enhanced binding is due to the presence of the additional contacts between the $\mathrm{C} 4$ amino-alkyl moiety of TOP-53 and the enzyme that were identified by STD $\left[{ }^{1} \mathrm{H}\right]-\mathrm{NMR}$.

\section{E-Ring Substituents}

Early structure-activity studies suggested that E-ring substituents on etoposide were important for drug function against mammalian type II topoisomerases $(35,39,40)$. As seen in Figure 2, this conclusion was confirmed for drug-induced DNA cleavage by yeast topoisomerase II. Removal of the 3'- and 5'-methoxyl groups from the E-ring of etoposide (hydroxyphenyletoposide; see Figures 1 and 2) decreased drug activity $\sim 60 \%$. Further removal of the 4'hydroxyl group (phenyl-etoposide; see Figures 1 and 2), decreased drug activity to nearly baseline.

The NMR experiments discussed above indicate that the E-ring of etoposide is intimately associated with topoisomerase II in the binary complex. Therefore, the effects of the 3'- and 5'-methoxyl, and the 4'-hydroxyl substituents on the interaction between etoposide and yeast topoisomerase II were monitored by STD [ $\left.{ }^{1} \mathrm{H}\right]-\mathrm{NMR}$. NOE signals for the E-ring H2' and H6' protons were observed for hydroxyphenyl-etoposide and phenyl-etoposide (Figure 6, top and third spectra, respectively). In addition, signals were observed for the H3' and H5' protons that replaced the corresponding methoxyl substituents in hydroxyphenyl-etoposide and phenyletoposide and the $\mathrm{H} 4$ ' proton that replaced the hydroxyl group in phenyl-etoposide. As observed for etoposide, the only other NOE signals seen corresponded to the geminal protons of the A-ring and the $\mathrm{H} 5$ and $\mathrm{H} 8$ protons of the B-ring. It should be noted that NOE signals for both drug derivatives were somewhat diminished as compared to the parent compound. 
The NMR results indicate that despite the loss of critical substituents, the pendant E-rings of hydroxyphenyl-etoposide and phenyl-etoposide still maintain a close association with topoisomerase II in the binary complex. This finding suggests that the 3'- and 5'-methoxyl groups and the 4'-hydroxyl of the E-ring are not required for drug binding. Therefore, nitrocellulose filter binding competition assays were employed to further define the contribution of these groups to drug binding. As seen in Figure 5, the ability of hydroxyphenyletoposide and phenyl-etoposide to compete with $\left[{ }^{3} \mathrm{H}\right]$ etoposide for binding to yeast topoisomerase II was similar to that of etoposide. On the basis of these results, we conclude that the 3'- and 5'- methoxyl groups and the 4'-hydroxyl of the etoposide E-ring play critical functional roles for drug action, but do not mediate binding of the drug to the type II enzyme.

\section{DISCUSSION}

Although etoposide is one of the most widely prescribed drugs used for the treatment of human cancers (1-4), the specific ring substituents that mediate its interactions with topoisomerase II have been impossible to define. However, the use of STD $\left[{ }^{1} \mathrm{H}\right]-\mathrm{NMR}$ has enabled drug-enzyme interactions to be characterized at the proton level. Results indicate that protons on the A-ring, B-ring, and pendent E-ring are in close contact with yeast topoisomerase II and human topoisomerase II $\alpha$ in the binary enzyme-ligand complex. These findings are summarized in Figure 7, which highlights hydrogens that interact with topoisomerase II in red and those for which no interactions were observed in green.

It has long been known that the glycosidic moiety of etoposide plays important physiological roles (1-4). The presence of this group keeps etoposide from interacting with tubulin and substitution of a thiophene for the 8"-methyl alters cellular uptake of the drug. Beyond these physiological functions, it is not clear whether the glycosidic moiety of etoposide plays any direct role in enhancing topoisomerase II-mediated DNA cleavage. To this point, no contacts were observed between topoisomerase II and any glycosidic protons and substitution of the thiophene at the 8" position had no effect on DNA scission. It is notable, however, that substitution of the glycosidic moiety with a flexible and charged amino-alkyl side chain, as in TOP-53, significantly enhanced drug-enzyme binding and drug activity against topoisomerase II. Furthermore, contacts were observed between the enzyme and every observable proton of this side chain in the binary complex. Therefore, while the $\mathrm{C}-4$ glycosidic moiety does not appear to mediate interactions between etoposide and topoisomerase II, other substituents at this position have the capacity to influence drug actions against its enzyme target.

Previous studies indicate that E-ring substituents are important for etoposide function (35, 37,39,40). Indeed, as seen in Figure 2, removal of the 3'- and 5'-methoxyl groups or the 4'hydroxyl moiety significantly impairs the ability of etoposide to enhance DNA cleavage mediated by yeast topoisomerase II. As determined by STD $\left[{ }^{1} \mathrm{H}\right]-\mathrm{NMR}$, every substituent on the E-ring is intimately associated with the protein in the binary complex. Since the E-ring has free rotation about the 1'-linkage to the C-ring, the $\mathrm{H} 2$ ' and $\mathrm{H} 6$ ' protons, as well as the 3'- and 5'-methoxyl groups are chemically equivalent and cannot be distinguished by NMR. A previous study by Long and co-workers found that removal of one of the two methoxyl groups had no obvious effect on levels of DNA scission (37). Thus, as shown in the shaded region in Figure 7, we propose that contacts between etoposide and topoisomerase II extend to only a portion of the E-ring.

Although the 3'-methoxyl, 5'-methoxyl, and 4'-hydroxyl moieties of the E-ring all are important for etoposide function $(35,39,40)$, none of them appear to contribute significantly to drug-enzyme binding. In fact, when these groups were replaced with hydrogen atoms, NOE signals were observed by STD $\left[{ }^{1} \mathrm{H}\right]-\mathrm{NMR}$ for all of the resulting protons. This finding suggests that protein associations with the E-ring may be mediated by stacking interactions rather than 
any specific group on the ring. In the absence of additional structural information, it is not known whether the 3'-methoxyl, 5'-methoxyl, or 4'-hydroxyl groups contribute to drug function through direct interactions with individual amino acids in topoisomerase II, or by subtly changing the overall geometry of the etoposide-enzyme-DNA complex.

In the absence of topoisomerase II, etoposide exhibits little if any ability to bind to DNA (29). However, the fact that the drug displays a DNA cleavage site specificity (preferring a cytosine at the base immediately 5 ' to the scissile bond $(5,53)$ implies that etoposide interacts with DNA in the ternary topoisomerase II-drug-nucleic acid complex. If this is the case, which portions of etoposide contact DNA in the active site of topoisomerase II? Given the strong contacts between the enzyme and the A-, B-, and E-rings we believe that these portions of the drug are unlikely to interact with DNA. Furthermore, substitution of a thiophene for the 8 "-methyl in teniposide or an amino alkyl chain in TOP-53 does not alter the DNA cleavage specificity of etoposide, and the amino alkyl substitution at the $\mathrm{C} 4$ position interacts strongly with topoisomerase II $(5,52,53)$. Consequently, we also believe that the glycoside moiety of etoposide probably does not contact DNA. Therefore, we propose that if any portions of etoposide interact with DNA in the active site of topoisomerase II, the C-and D-rings are the most likely candidates. Future studies with the ternary enzyme-drug-DNA complex will be required to address this hypothesis directly.

Finally, it should be noted that there is a strong correlation between results obtained from STD $\left[{ }^{1} \mathrm{H}\right]$-NMR experiments and DNA cleavage assays. Alterations in etoposide substituents that contact the enzyme in the binary complex diminished the ability of the drug to enhance topoisomerase II-mediated DNA cleavage. Conversely, alterations in drug substituents that increased the number of contacts between the enzyme and etoposide raised levels of DNA scission. Therefore, STD $\left[{ }^{1} \mathrm{H}\right]-\mathrm{NMR}$ results with the binary enzyme-drug complex appear to have predictive value that may contribute to the future development of etoposide derivatives with greater activity against topoisomerase II.

\section{Supplementary Material}

Refer to Web version on PubMed Central for supplementary material.

\section{REFERENCES}

1. Hande KR. Etoposide: four decades of development of a topoisomerase II inhibitor. Eur. J. Cancer 1998;34:1514-1521. [PubMed: 9893622]

2. Hande KR. Clinical applications of anticancer drugs targeted to topoisomerase II. Biochim. Biophys. Acta 1998;1400:173-184. [PubMed: 9748560]

3. Holden JA. DNA topoisomerases as anticancer drug targets: from the laboratory to the clinic. Curr. Med. Chem. Anticancer Agents 2001;1:1-25. [PubMed: 12678768]

4. Baldwin EL, Osheroff N. Etoposide, topoisomerase II and cancer. Curr. Med. Chem. Anti-Canc. Agents 2005;5:363-372.

5. Ross W, Rowe T, Glisson B, Yalowich J, Liu L. Role of topoisomerase II in mediating epipodophyllotoxin-induced DNA cleavage. Cancer Res 1984;44:5857-5860. [PubMed: 6094001]

6. Wang JC. DNA Topoisomerases. Annu. Rev. Biochem 1996;65:635-692. [PubMed: 8811192]

7. Nitiss JL. Investigating the biological functions of DNA topoisomerases in eukaryotic cells. Biochim. Biophys. Acta 1998;1400:63-81. [PubMed: 9748506]

8. Wang JC. Moving one DNA double helix through another by a type II DNA topoisomerase: the story of a simple molecular machine. Quart. Rev. Biophys 1998;31:107-144.

9. Fortune JM, Osheroff N. Topoisomerase II as a target for anticancer drugs: when enzymes stop being nice. Prog. Nucleic Acid. Res. Mol. Biol 2000;64:221-253. [PubMed: 10697411] 
10. Champoux JJ. DNA topoisomerases: structure, function, and mechanism. Annu. Rev. Biochem 2001;70:369-413. [PubMed: 11395412]

11. Wang JC. Cellular roles of DNA topoisomerases: a molecular perspective. Nat. Rev. Mol. Cell. Biol 2002;3:430-440. [PubMed: 12042765]

12. Velez-Cruz, R.; Osheroff, N. DNA Topoisomerases: Type II. In: Lennarz, W.; Lane, MD., editors. Encyclopedia of Molecular Biology. San Diego: Elsevier Science; 2004. p. 806-811.

13. Osheroff N. Effect of antineoplastic agents on the DNA cleavage/religation reaction of eukaryotic topoisomerase II: inhibition of DNA religation by etoposide. Biochemistry 1989;28:6157-6160. [PubMed: 2551366]

14. Robinson MJ, Osheroff N. Effects of antineoplastic drugs on the post-strand-passage DNA cleavage/ religation equilibrium of topoisomerase II. Biochemistry 1991;30:1807-1813. [PubMed: 1847075]

15. Kaufmann SH. Cell death induced by topoisomerase-targeted drugs: more questions than answers. Biochim. Biophys. Acta 1998;1400:195-211. [PubMed: 9748575]

16. Kaufmann SH, Gore SD, Miller CB, Jones RJ, Zwelling LA, Schneider E, Burke PJ, Karp JE. Topoisomerase II and the response to antileukemic therapy. Leukemia Lymph 1998;29:217-237.

17. Rowley JD. The critical role of chromosome translocations in human leukemias. Ann. Rev. Genet 1998;32:495-519. [PubMed: 9928489]

18. Felix CA. Secondary leukemias induced by topoisomerase-targeted drugs. Biochim. Biophys. Acta 1998;1400:233-255. [PubMed: 9748598]

19. Wilstermann AM, Osheroff N. Stabilization of eukaryotic topoisomerase II-DNA cleavage complexes. Curr. Top. Med. Chem 2003;3:321-338. [PubMed: 12570766]

20. Sordet O, Khan QA, Kohn KW, Pommier Y. Apoptosis induced by topoisomerase inhibitors. Curr. Med. Chem. Anti-Canc. Agents 2003;3:271-290.

21. Felix CA, Kolaris CP, Osheroff N. Topoisomerase II and the etiology of chromosomal translocations. DNA Repair (Amst) 2006;5:1093-1108. [PubMed: 16857431]

22. Sullivan DM, Latham MD, Rowe TC, Ross WE. Purification and characterization of an altered topoisomerase II from a drug-resistant Chinese hamster ovary cell line. Biochemistry 1989;28:5680_ 5687. [PubMed: 2550059]

23. Beck WT, Danks MK, Wolverton JS, Kim R, Chen M. Drug resistance associated with altered DNA topoisomerase II. Adv. Enzyme Regul 1993;33:113-127. [PubMed: 8395133]

24. Nitiss JL. Using yeast to study resistance to topoisomerase II-targeting drugs. Cancer Chemother. Pharmacol 1994;34:S6-S13. [PubMed: 8070029]

25. Vassetzky YS, Alghisi GC, Gasser SM. DNA Topoisomerase II Mutations and Resistance to Antitumor Drugs. BioEssays 1995;17:767-774. [PubMed: 8763829]

26. Elsea SH, Hsiung Y, Nitiss JL, Osheroff N. A yeast type II topoisomerase selected for resistance to quinolones. Mutation of histidine 1012 to tyrosine confers resistance to nonintercalative drugs but hypersensitivity to ellipticine. J. Biol. Chem 1995;270:1913-1920. [PubMed: 7829529]

27. Burden DA, Osheroff N. Mechanism of action of eukaryotic topoisomerase II and drugs targeted to the enzyme. Biochim. Biophys. Acta 1998;1400:139-154. [PubMed: 9748545]

28. Larsen AK, Skladanwski A. Cellular resistance to topoisomerase-targeted drugs: from drug uptake to cell death. Biochim. Biophys. Acta 1998;1400:257-274. [PubMed: 9748618]

29. Chow KC, Macdonald TL, Ross WE. DNA binding by epipodophyllotoxins and N-acyl anthracyclines: implications for mechanism of topoisomerase II inhibition. Mol. Pharmacol 1988;34:467-473. [PubMed: 2845248]

30. Kingma PS, Burden DA, Osheroff N. Binding of etoposide to topoisomerase II in the absence of DNA: decreased affinity as a mechanism of drug resistance. Biochemistry 1999;38:3457-3461. [PubMed: 10090731]

31. Leroy D, Kajava AV, Frei C, Gasser SM. Analysis of etoposide binding to subdomains of human DNA topoisomerase II alpha in the absence of DNA. Biochemistry 2001;40:1624-1634. [PubMed: 11327821]

32. Burden DA, Kingma PS, Froelich-Ammon SJ, Bjornsti M-A, Patchan MW, Thompson RB, Osheroff N. Topoisomerase II-etoposide interactions direct the formation of drug-induced enzyme-DNA cleavage complexes. J. Biol. Chem 1996;46:29238-29244. [PubMed: 8910583] 
33. Loike JD. VP16-213 and podophyllotoxin. A study on the relationship between chemical structure and biological activity. Cancer Chemother. Pharmacol 1982;7:103-111. [PubMed: 7044591]

34. Long BH, Musial ST, Brattain MG. Comparison of cytotoxicity and DNA breakage activity of congeners of podophyllotoxin including VP16-213 and VM26: a quantitative structure-activity relationship. Biochemistry 1984;23:1183-1188. [PubMed: 6712942]

35. Long BH. Structure-activity relationships of podophyllin congeners that inhibit topoisomerase II. NCI Monogr 1987;4:123-127. [PubMed: 3041239]

36. van Maanen JM, Retel J, de Vries J, Pinedo HM. Mechanism of action of antitumor drug etoposide: a review. J. Natl. Cancer Inst 1988;80:1526-1533. [PubMed: 2848132]

37. Saulnier MG, Vyas DM, Langley DR, Doyle TW, Rose WC, Crosswell AR, Long BH. E-ring desoxy analogues of etoposide. J. Med. Chem 1989;32:1418-1420. [PubMed: 2738876]

38. Sinha BK, Politi PM, Eliot HM, Kerrigan D, Pommier Y. Structure-activity relations, cytotoxicity and topoisomerase II dependent cleavage induced by pendulum ring analogues of etoposide. Eur. J. Cancer 1990;26:590-593. [PubMed: 2169277]

39. Long BH. Mechanisms of action of teniposide (VM-26) and comparison with etoposide (VP-16). Semin. Oncol 1992;19:3-19. [PubMed: 1329225]

40. Long BH, Casazza AM. Structure-activity relationships of VP-16 analogues. Cancer Chemother. Pharmacol 1994;34:S26-S31. [PubMed: 8070024]

41. Damayanthi Y, Lown JW. Podophyllotoxins: current status and recent developments. Curr. Med. Chem 1998;5:205-252. [PubMed: 9562603]

42. Lee KH. Anticancer drug design based on plant-derived natural products. J. Biomed. Sci 1999;6:236250. [PubMed: 10420081]

43. Chen A, Shapiro MJ. Affinity NMR. Anal. Chem 1999;71:669A-675A.

44. Roberts GC. NMR spectroscopy in structure-based drug design. Curr. Opin. Biotechnol 1999;10:4247. [PubMed: 10047507]

45. Mayer M, Meyer B. Characterization of Ligand Binding by Saturation Transfer Difference NMR Spectroscopy. Angew. Chem. Int. Ed. Engl 1999;38:1784-1788.

46. Mayer M, Meyer B. Group epitope mapping by saturation transfer difference NMR to identify segments of a ligand in direct contact with a protein receptor. J. Am. Chem. Soc 2001;123:61086117. [PubMed: 11414845]

47. Pellecchia M, Sem DS, Wuthrich K. NMR in drug discovery. Nat. Rev. Drug Discov 2002;1:211219. [PubMed: 12120505]

48. Worland ST, Wang JC. Inducible overexpression, purification, and active site mapping of DNA topoisomerase II from the yeast Saccharomyces cerevisiae. J. Biol. Chem 1989;264:4412-4416. [PubMed: 2538443]

49. Kingma PS, Greider CA, Osheroff N. Spontaneous DNA lesions poison human topoisomerase II $\alpha$ and stimulate cleavage proximal to leukemic 11q23 chromosomal breakpoints. Biochemistry 1997;36:5934-5939. [PubMed: 9166762]

50. Jardine I, Strife RJ, Kozlowski J. Synthesis, 470-MHz 1H NMR spectra, and activity of delactonized derivatives of the anticancer drug etoposide. J. Med. Chem 1982;25:1077-1081. [PubMed: 7131486]

51. Utsugi T, Shibata J, Sugimoto Y, Aoyagi K, Wierzba K, Kobunai T, Terada T, Oh-hara T, Tsuruo T, Yamada Y. Antitumor activity of a novel podophyllotoxin derivative (TOP-53) against lung cancer and lung metastatic cancer. Cancer Res 1996;56:2809-2814. [PubMed: 8665518]

52. Byl JA, Cline SD, Utsugi T, Kobunai T, Yamada Y, Osheroff N. DNA topoisomerase II as the target for the anticancer drug TOP-53: mechanistic basis for drug action. Biochemistry 2001;40:712-718. [PubMed: 11170388]

53. Capranico G, Binaschi M. DNA sequence selectivity of topoisomerases and topoisomerase poisons. Biochim. Biophys. Acta 1998;1400:185-194. [PubMed: 9748568] 
C4 Substitutions

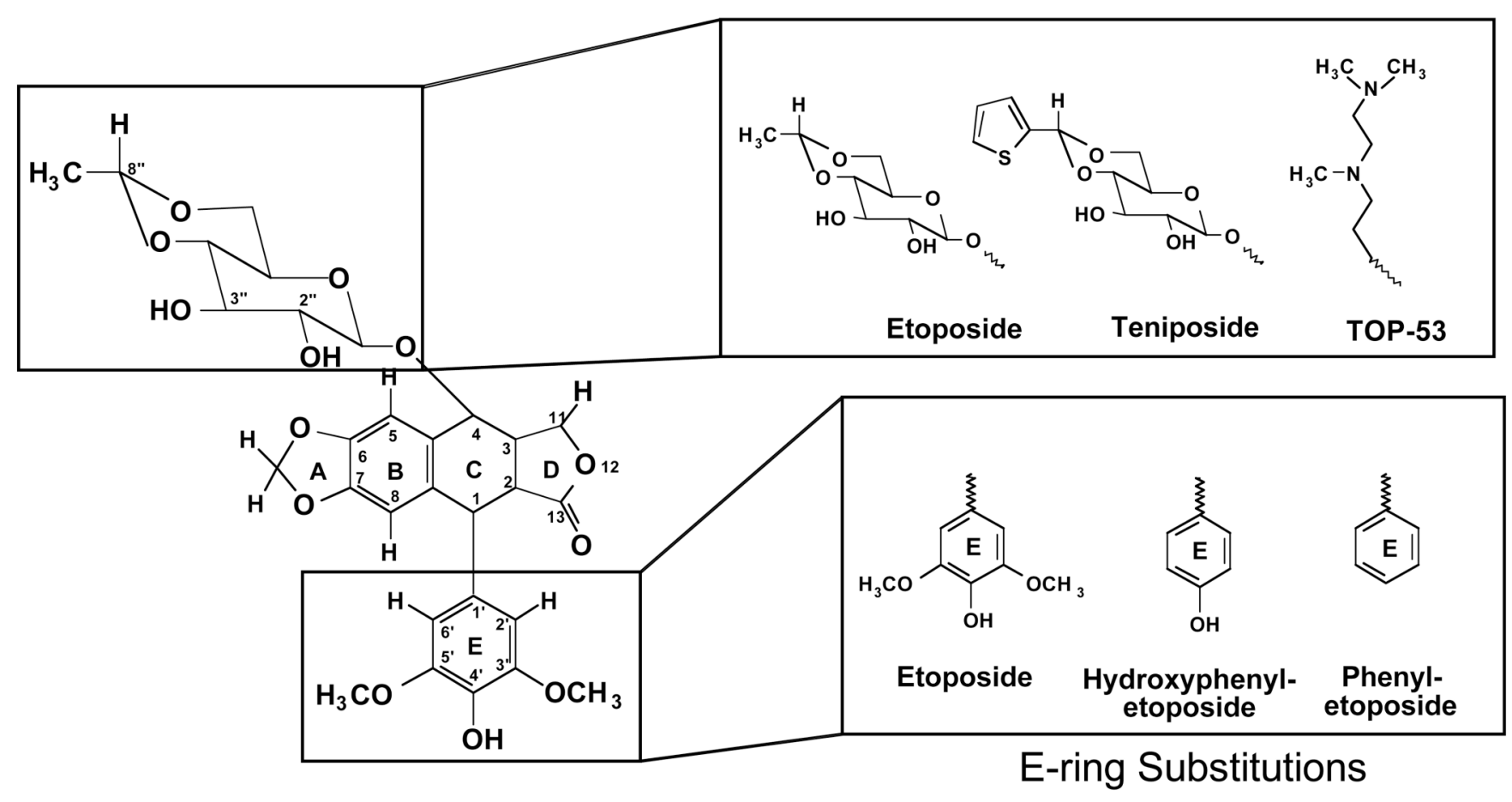

FIGURE 1.

Structures of etoposide and etoposide derivatives with C4 or C1 (E-ring) substitutions that were employed in the present study. 
C4 Substitutions

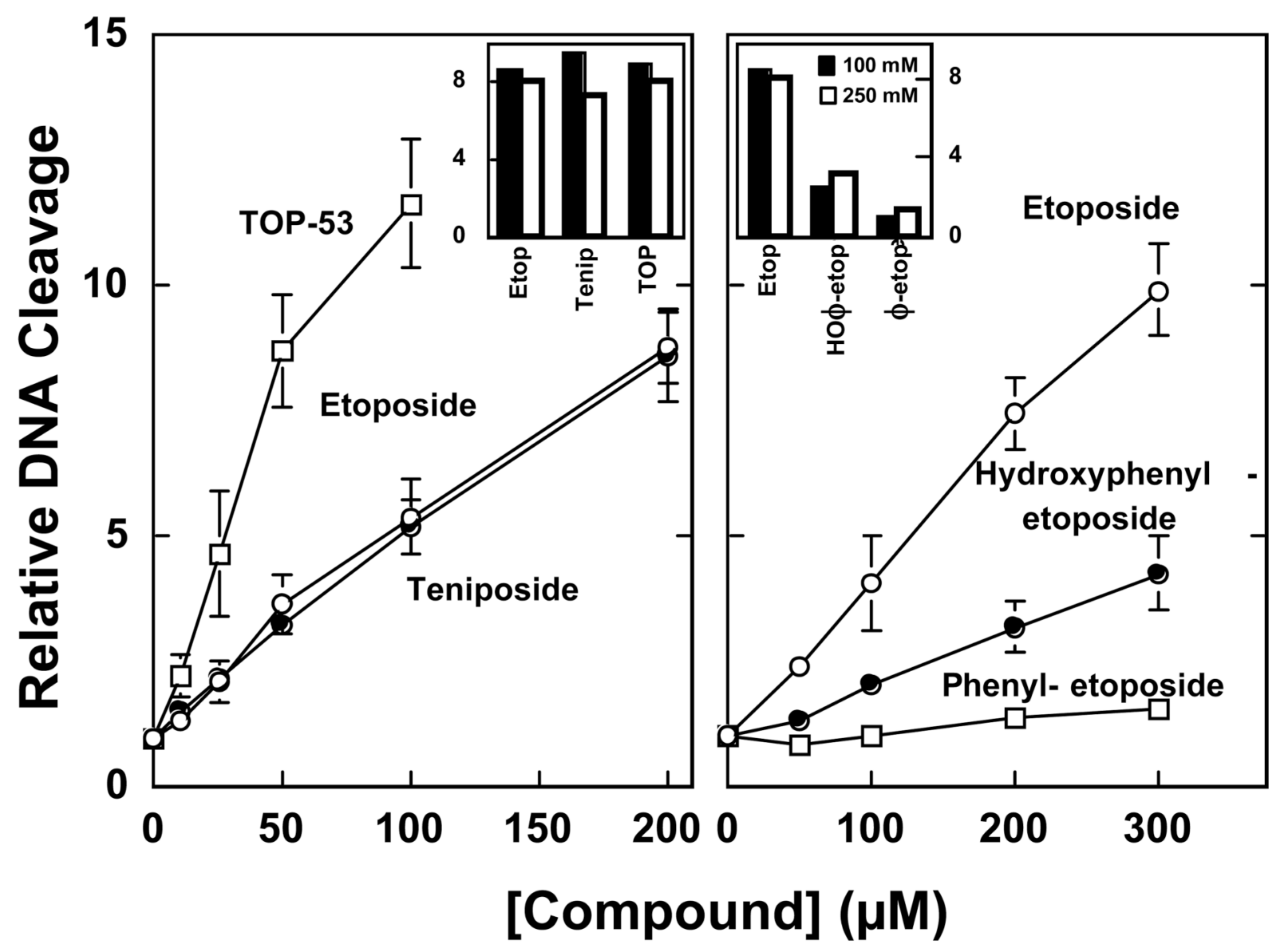

FIGURE 2.

Etoposide derivatives stimulate DNA cleavage mediated by yeast topoisomerase II. Levels of DNA cleavage were expressed as a fold-enhancement over reactions that were carried out in the absence of drug. Cleavage titrations using etoposide derivatives with $\mathrm{C} 4$ substitutions (left panel) or E-ring substitutions (right panel) are shown. Left: Assay mixtures contained 0-200 $\mu \mathrm{M}$ etoposide (open circles) or teniposide (closed circles), or 0-100 $\mu \mathrm{M}$ TOP-53 (open squares). Higher concentrations of TOP-53 generated multiple cleavage events per plasmid and therefore are not shown. Right: Assay mixtures contained 0-300 $\mu \mathrm{M}$ etoposide (open circles), hydroxyphenyl-etoposide (closed circles), or phenyl-etoposide (open squares). Error bars represent the standard deviation of three independent experiments. Insets show cleavage reactions carried out in cleavage buffer containing $100 \mathrm{mM} \mathrm{KCl}$ (filled bars) or $250 \mathrm{mM} \mathrm{KCl}$ (open bars) the presence of $200 \mu \mathrm{M}$ etoposide (Etop), teniposide (Tenip), hydroxyphenyletoposide (HO- $\varphi$-etop), or phenyl-etoposide ( $\varphi$-etop), or $100 \mu \mathrm{M}$ TOP-53 (TOP). 


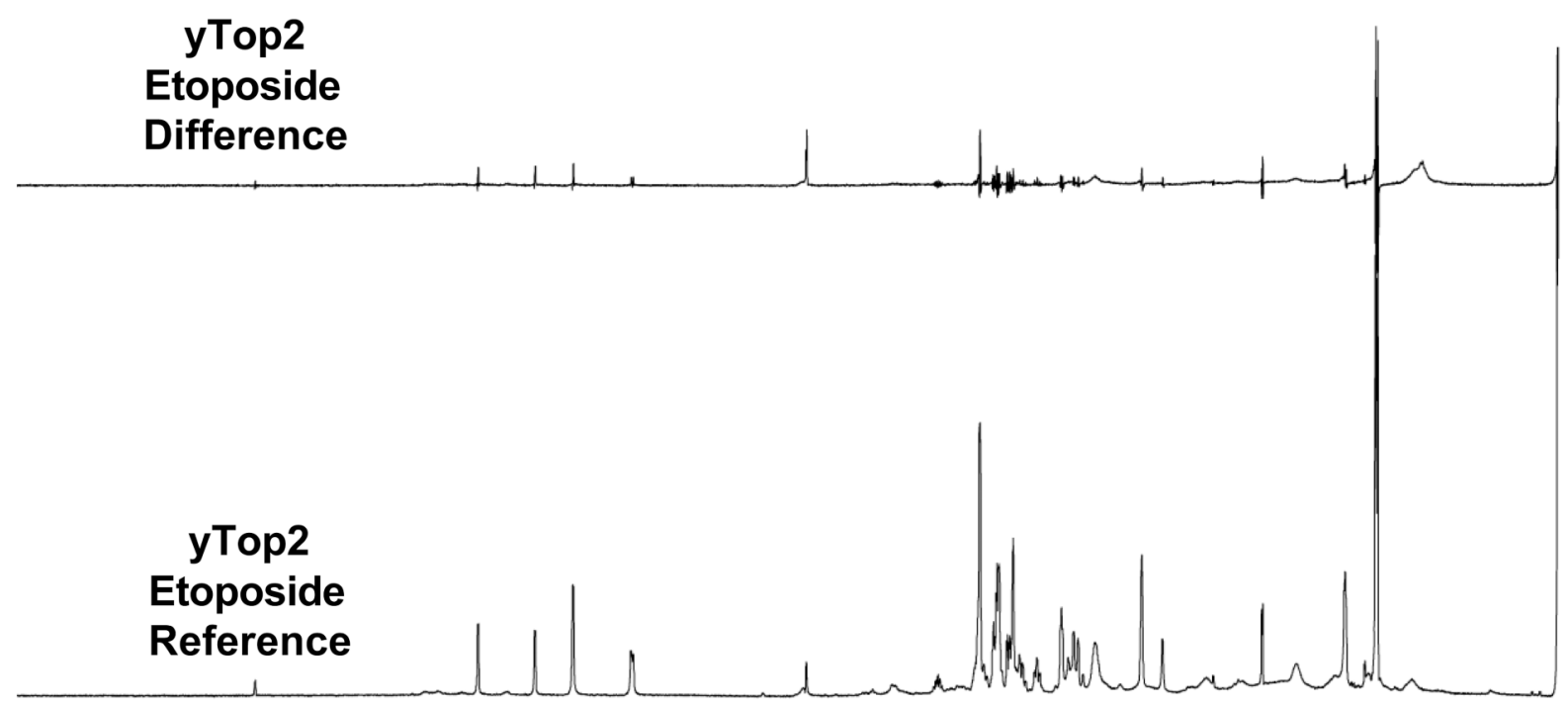

hTop2 $\alpha$

Etoposide

Difference

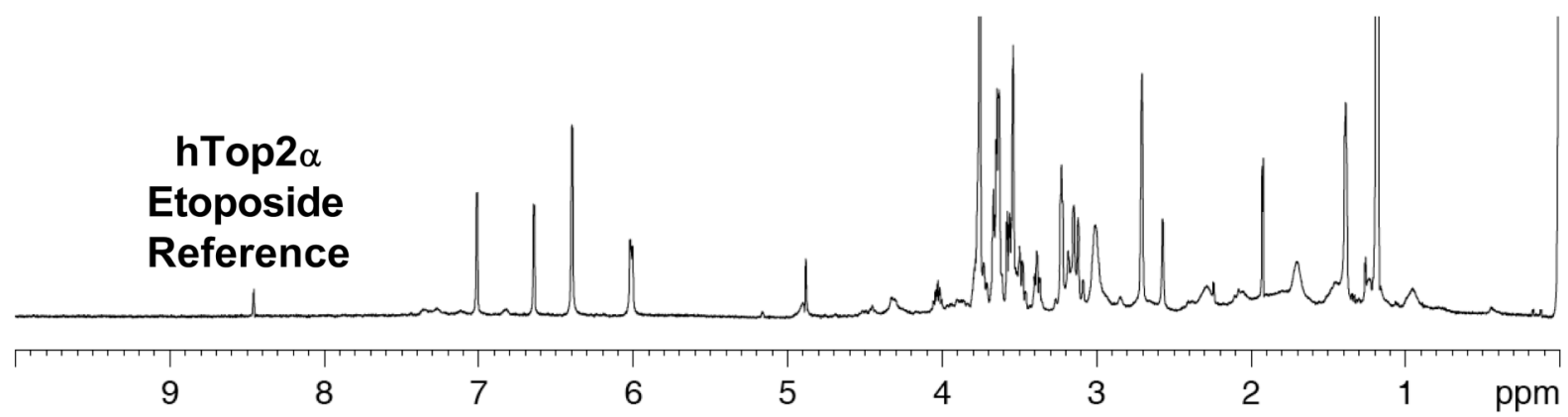

FIGURE 3.

Interaction of etoposide with yeast topoisomerase II and human topoisomerase II $\alpha$ as determined by STD $\left[{ }^{1} \mathrm{H}\right]-\mathrm{NMR}$ spectroscopy. 1D $\left[{ }^{1} \mathrm{H}\right]-\mathrm{NMR}$ reference spectra of etoposide are shown in the second and fourth spectrum from the top. 1D STD [ $\left.{ }^{1} \mathrm{H}\right]-\mathrm{NMR}$ spectra of etoposide in the presence of yeast topoisomerase II (top spectrum) or human topoisomerase II $\alpha$ (third spectrum from top) also are shown. Spectra are representative of at least three independent experiments. 


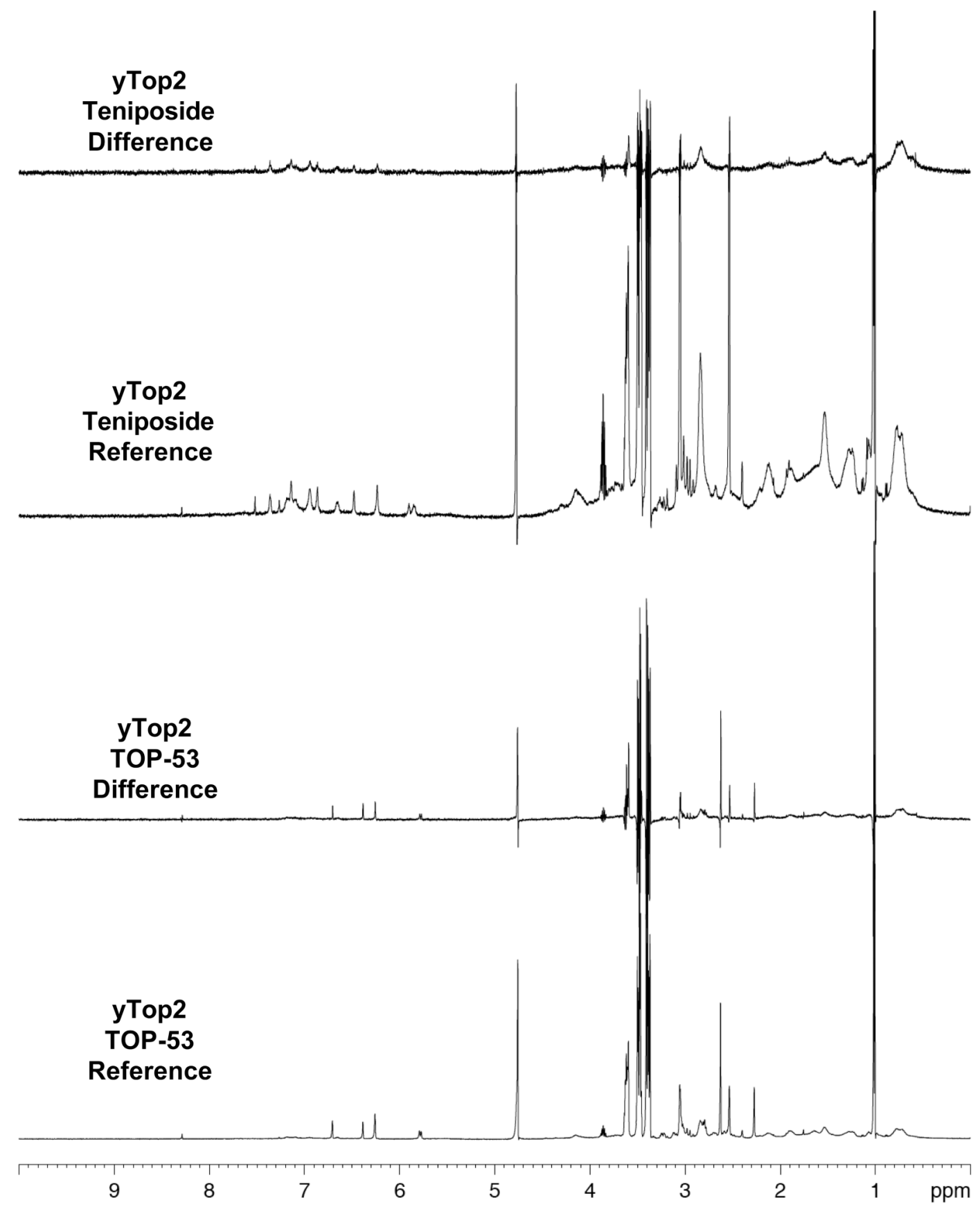

FIGURE 4.

Interaction of teniposide and TOP-53 with yeast type II topoisomerase as determined by STD $\left[{ }^{1} \mathrm{H}\right]$-NMR spectroscopy. 1D $\left[{ }^{1} \mathrm{H}\right]-\mathrm{NMR}$ reference spectra of teniposide (second spectrum from top) and TOP-53 (fourth spectrum from top) are shown. 1D STD $\left[{ }^{1} \mathrm{H}\right]-\mathrm{NMR}$ spectra of teniposide (top spectrum) and TOP-53 (third spectrum from top) in the presence of yeast topoisomerase II also are shown. Spectra are representative of at least three independent experiments. 
C4 Substitutions

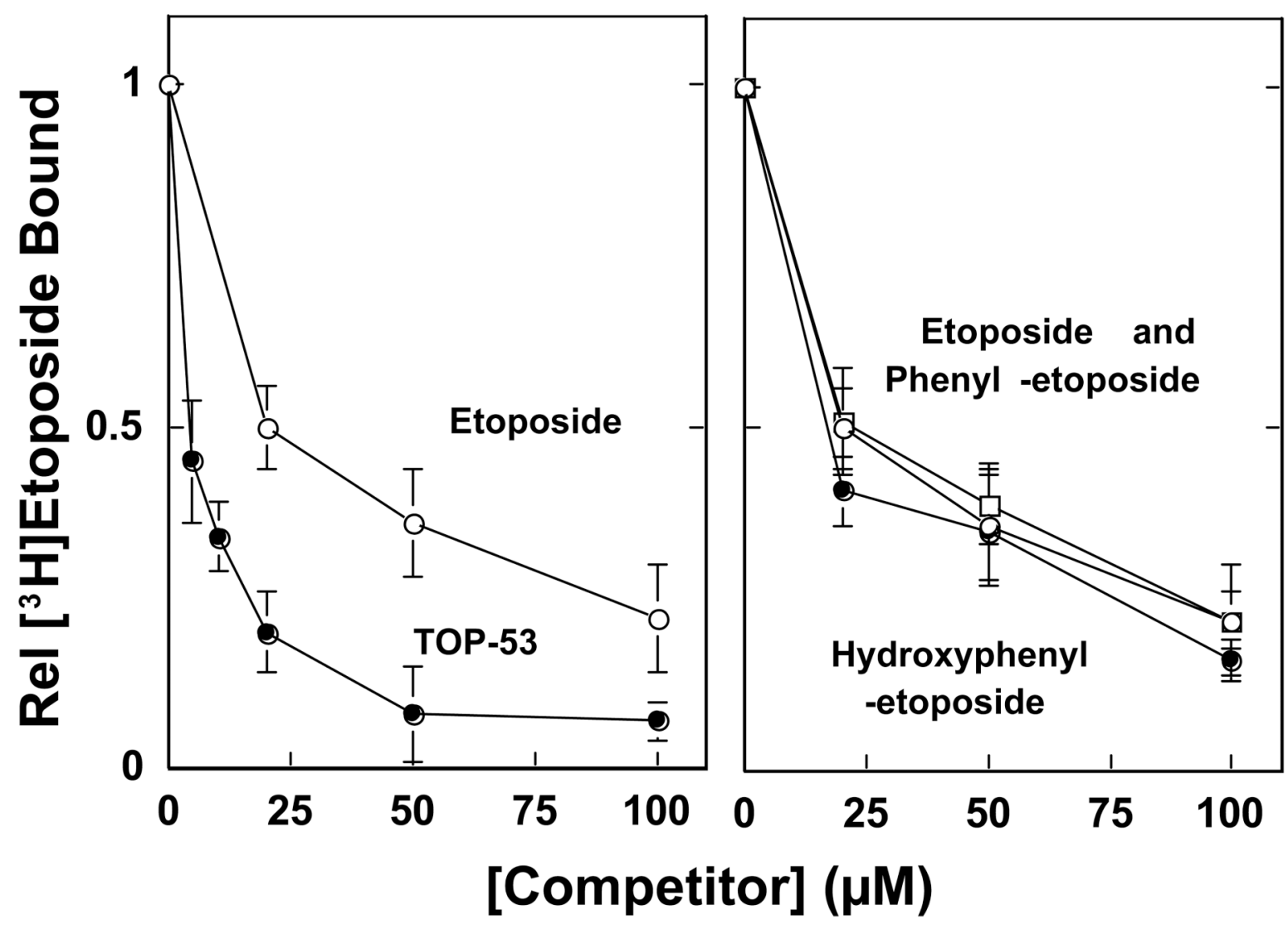

1 d D

0.5 ڤ 옹

FIGURE 5.

Binding of etoposide and derivatives to yeast topoisomerase II. Left: Reaction mixtures contained $20 \mu \mathrm{M}\left[{ }^{3} \mathrm{H}\right]$ etoposide and 0-100 $\mu \mathrm{M}$ etoposide (open circles) or TOP-53 (closed circles). Right: Reaction mixtures contained $20 \mu \mathrm{M}\left[{ }^{3} \mathrm{H}\right]$ etoposide and $0-100 \mu \mathrm{M}$ etoposide (open circles), hydroxyphenyl-etoposide (closed circles), or phenyl-etoposide (open squares). Levels of $\left[{ }^{3} \mathrm{H}\right]$ etoposide binding to yeast topoisomerase II observed in the absence of competitor drug were set to 1 . Error bars represent the standard deviation of three independent experiments. 

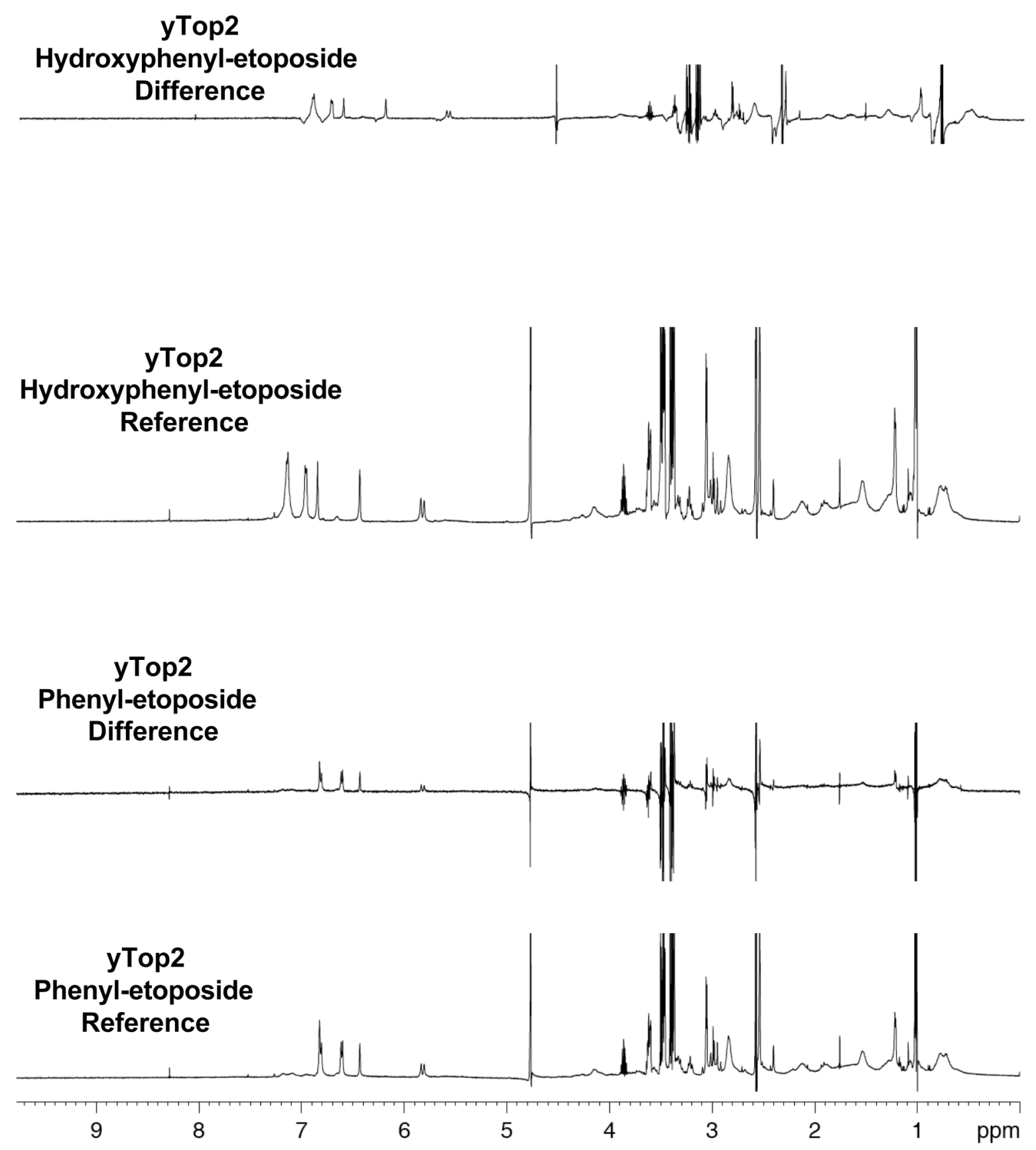

FIGURE 6.

Interaction of hydroxyphenyl-etoposide and phenyl-etoposide with yeast type II topoisomerase as determined by STD $\left[{ }^{1} \mathrm{H}\right]$-NMR spectroscopy. 1D $\left[{ }^{1} \mathrm{H}\right]$-NMR reference spectra of hydroxyphenyl-etoposide (second spectrum from top) and phenyl-etoposide (fourth spectrum from top) are shown. 1D STD $\left[{ }^{1} \mathrm{H}\right]-\mathrm{NMR}$ spectra of hydroxyphenyl-etoposide (top spectrum) and phenyl-etoposide (third spectrum from top) in the presence of yeast topoisomerase II also are shown. Spectra are representative of at least three independent experiments. 


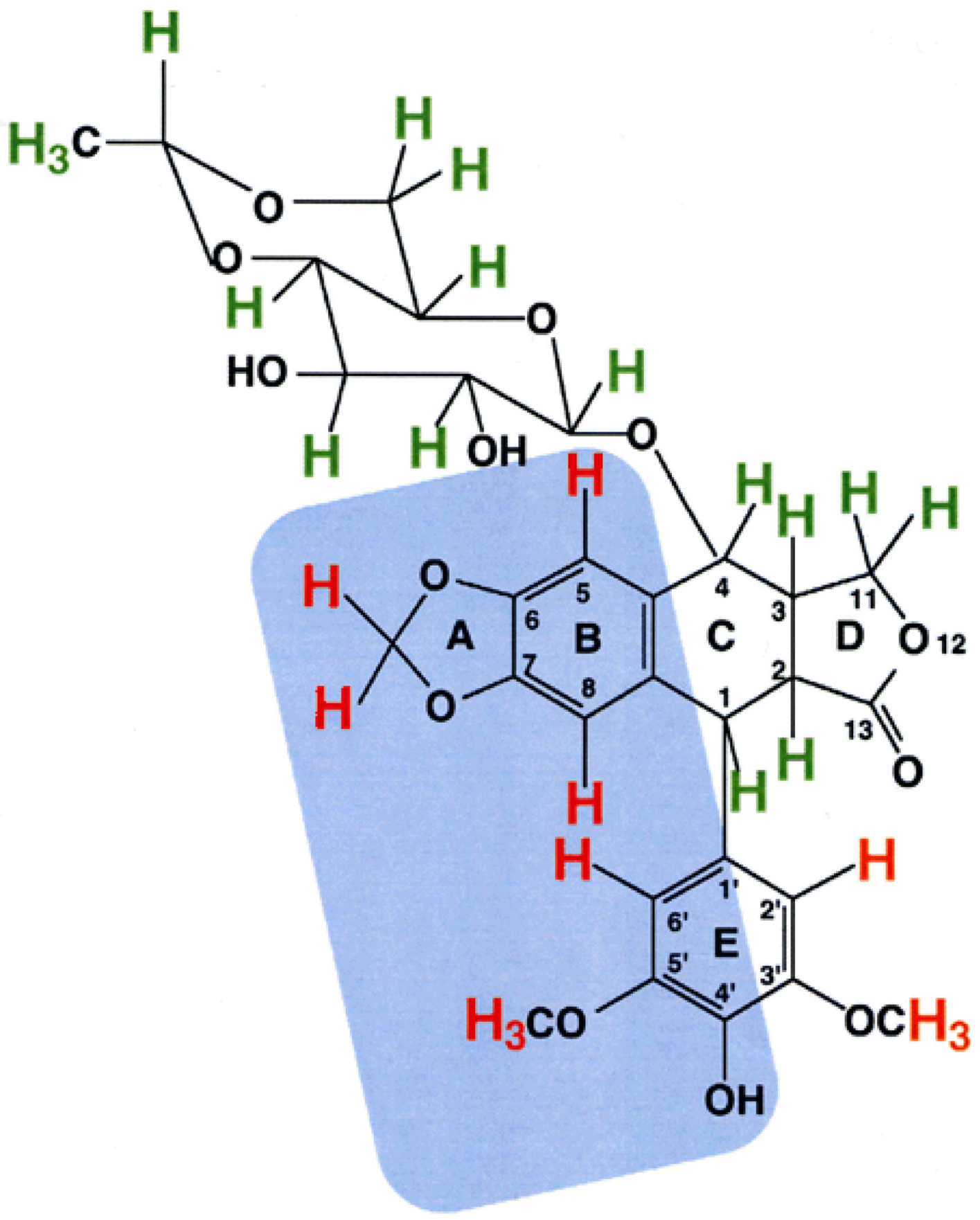

FIGURE 7.

Summary of etoposide substituents that interact with type II topoisomerases. Protons that interact with the enzyme are shown in red, those that do not are shown in green. Hydroxyl protons that were obscured by the water peak and could not be visualized are indicated in black. The shaded region on etoposide, including portions of the $\mathrm{A}-, \mathrm{B}-$ and $\mathrm{E}$-rings, is proposed to interact with topoisomerase II in the binary drug-enzyme complex. 